Type of the Paper: Article.

\title{
Garlic as Alternative Therapy to Treat Uropathogene Bacteria in Women with Urinary Tract Infection in Lomé, Togo
}

\author{
Banfitebiyi Gambogou', Abdoul Karim Ouattara ${ }^{2}$, Essodolom Taale 1,3, Simplice D. Karou, ${ }^{1,2}$ \\ Yaovi A. Ameyapoh ${ }^{1 *}$, Jacques Simpore ${ }^{2}$ \\ ${ }^{1}$ Ecole Supérieure des Techniques Biologiques et Alimentaires, Laboratoire de Microbiologie et de Contrôle \\ Qualité des Denrées Alimentaires, Centre de Recherche et de Formation sur les Plantes Médicinales \\ (CERFOPLAM), Université de Lomé B.P. 1515 Lomé-TOGO ; Tél. :(228) 222564 35- Fax : (228) 22218595. \\ E-mail : lamicodaestba.ul@gmail.com . \\ ${ }^{2}$ Université Ouaga I Pr Joseph Ki-Zerbo, 03 BP 7021 Ouagadougou 03; Tél : +226 25307064 / 65 - Fax : +226 \\ 25307242 Site web: $\underline{w w w . l a b i o g e n e . o r g, ~ O u a g a d o u g o u, ~ B u r k i n a ~ F a s o . ~}$ \\ ${ }^{3}$ Faculté des Sciences Fondamentales et Appliquées, Universités des Sciences et Technologies de Cote d'Ivoire \\ (USTCI), 01BP1482 Abidjan01, République de la Côte d'Ivoire.
}

\begin{abstract}
The urinary tract infection (UTI) is the most common bacterial infection, especially in women. The increased incidence of UTIs, at the last decades have paralleled with the growing emergence of antibiotic resistance. The aim is to evaluate aqueous garlic extract (AGE) susceptibility against multidrug-resistant (MDR) bacteria isolated in urine of women. The investigation of antibacterial propriety and time kill effect of AGE was performed by the well method, microdilution method and spectrophotometer assay. Antibiotics susceptibility assay revealed that the nine MDR bacteria had high resistance against Amoxicillin/ clavulanic acid $(100 \%)$ and Erythromycin (100\%), Cefotaxime $(83.33 \%)$ and Ceftazidime $(83.33 \%)$. AGE exhibited potent antibacterial activity against the nine MDR bacteria tested. In Gram-negative bacteria, the inhibition diameters ranged from $20 \pm 3$ to $32 \pm 4 \mathrm{~mm}$, with Minimum Inhibitory Concentrations (MICs) ranging from $10 \%$ to $12.5 \%(\mathrm{w} / \mathrm{v})$ and Minimum Bactericidal Concentration (MBCs) was $12.5 \%$ (w/v). Gram-positive bacteria exhibited diameters ranging from $38 \pm 2$ to $45 \pm 1 \mathrm{~mm}$; MIC and $\mathrm{MBC}$ values ranged from 05 to $10 \%(\mathrm{w} / \mathrm{v})$ and were found more susceptible than Gram-negative bacteria. To conclude, this investigation shown that AGE have high potential antibacterial to use as an alternative to treat women UTIs.
\end{abstract}

Keywords: Garlic, Antibiotics, Lomé, Uropathogenic bacteria, Urinary Tract Infection, Multidrug resistance and alternative therapy.

\section{Introduction}

The urinary tract infection (UTI) is the most common bacterial infection, especially in women, since it is estimated that $50 \%$ of women will have at least one urinary infection during their lifetime[1]. Economic burden of the society, the UTI is responsible for nearly seven million external visits and one million emergency visits, resulting in over 100000 hospitalizations annually in the United States[2]. In community settings, it mainly affects women sexually active, while in the middle hospitable, it is the elderly and the carriers, which are the most affected. In general, UTIs are associated with a single bacterium. Bacteria most often involved in UTIs acquired in a community are Escherichia coli and Staphylococcus saprophyticus, responsible for more than $80 \%$ and $10 \%$ to $15 \%$ of UTI, respectively [3, 4]. Occasionally other microorganisms, such as Klebsiella spp., Proteus mirabilis, and Enterococcus faecalis, can be involved[1,5]. Despite the increased incidence of UTIs globally, the last decades have paralleled the growing emergence of antibiotic resistance. Antimicrobial resistance in UTIs has reported worldwide and increasing rates of resistance is a 
growing concern in both developed and developing countries[6, 7]. Multidrug resistant, pose treatment problem resulting in high morbidity, high mortality, and increased health care costs[8]. The multidrug resistant (MDR) strains are major public threat worldwide[9] and are highly prevalent in Togo[10, 11]. Antimicrobial resistance is a leading concern and efforts should made to ensure an appropriate duration of therapy for symptomatic infections[12]. Although, in several countries, medical herbal are already used in their health care.

In all developing countries, such as Togo, medicinal plants are the most widely used means, especially in rural areas, for solving public health problems. At present, the situation regarding the abundance and availability of plants in general and medicinal plants in particular remains poorly known. The search on medicinal plants, generally devoted to ethnobotanical surveys, made it possible to draw up a non-exhaustive list of plant species used in traditional medicine by the populations[13, 14]. The study of biological and chemical properties has shown that Togolese flora has a real therapeutic and nutritional potential that can be used to treat or prevent many diseases. This is the case of Karou et al.[15] and Tchacondo et al.[16], who have shown the potential of some medicinal plants in the treatment and control of infections. These infections are one of the leading causes of death and economic loss. Plants have an interest in human health for their antibacterial [15, 17], antifungal[18] and antiplasmodial activities[19].

Allium sativum commonly known as garlic have documented and valued for their spicy and medicinal qualities by many cultures around the globe for many years[20]. Garlic is the edible bulb of the lily (liliaceae) family, which is widely used as a spice in flavoring, as foodstuff, and condiment around the world[21]. Garlic has been used to treat bacterial related diseases such as pile, cough and rheumatism; also, to alleviate tumor, cardiovascular diseases and ageing[22]. Now, garlic has been known for his antibacterial, antifungal, and antiviral properties[23, 24]. Garlic have been shown to have a wide spectrum antibacterial activity, including effects on Escherichia, Salmonella, Staphylococcus, Streptococcus, Klebsiella, Proteus, Mycobacterium, and Helicobacter species[24, 25].

No data on the antimicrobial activity of garlic grown in Togo and its use in the treatment of urinary tract infections exists in the literature. Then objective of this study was to evaluate the antibacterial activity of fresh garlic bulbs against uropathogenic bacteria isolated from the "Centre Hospitalier Regional - Lomé Commune" in women with urinary tract infection in the aim to propose the use of garlic in the treatment of urinary tract infections caused by multidrug resistant bacteria.

\section{Materials and Methods}

\section{Plant Material}

Fresh bulbs of Allium sativum L., commonly known as garlic ("AYO" in the local name) were purchased from "ADWLATO" market, the famous spices market of Lomé, capital city of Togo and stored at Laboratory temperature $24 \pm 1^{\circ} \mathrm{C}$.

Ethics:

Our studies performed did not have direct links with women. We used only bacteria strains isolated in urine of women bring for analysis. The investigator of the study have not information about the origin of urine (de l'identité des femmes dont les urines ont été utilize pour l'isolement des bacteries).

\section{Bacteria strains}

Nine bacterial strains were isolated from the urine of women hospitalize or come for consultation at "Centre Hospitalier Regional - Lomé" (Togo). These bacteria strains are Escherichia coli, Staphylococcus saprophyticus, Klebsiella oxytoca, Klebsiella pneumoniae, Citrobacter freundii, Proteus 
mirabilis, Staphylococcus aureus, Enterobacter aerogenes and Enterococcus faecalis. Bacteria strains tested were identified by conventional methods of microbiology and used API 20E and API STAPH (Biomerieux, Paris, France).

\section{Antibiotics susceptibility of uropathogenic bacteria strains}

An inoculum of each strain was prepared, and the turbidity of the suspension was adjusted to achieve 0.5 McFarland with the absorbance range of 0.09 by UV-Vis spectrophotometer at wavelength of $620 \mathrm{~nm}$. The antibiotic susceptibility were tested by Kirby Bauer disc diffusion method according to the Clinical and Laboratory Standards Institute[26] using Mueller Hinton agar medium (Oxoid, Hampshire, England). The antimicrobial agents tested were Gentamicin (10 $\mu \mathrm{g})$, Imipenem $(30 \mu \mathrm{g})$, Ceftazidime $(30 \mu \mathrm{g})$, Cefoxitin $(30 \mu \mathrm{g})$, Cefotaxime $(30 \mu \mathrm{g})$, , Amikacin $(30 \mu \mathrm{g})$, Amoxicillin + Clavulanic acid $(20 / 10 \mu g)$, Ciprofloxacin $(5 \mu g)$, Nalidixic acid (30 $\mu g)$ Vancomycin (30

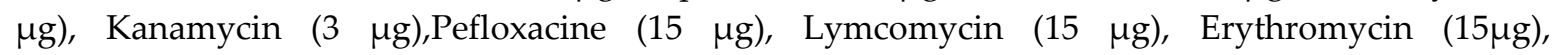
Chloramphenicol (30 $\mu \mathrm{g})$ (Oxoid, England). Resistance data were interpreted according to National Committee for Clinical laboratory Standards (NCCLS, 1993).

\section{Antibacterial Activity of garlic}

\section{AGE susceptibility against the nine multidrug resistance bacteria by well diffusion.}

After adjusting the inoculum to a $0.5 \mathrm{McFarland}$ unit turbidity standard, a sterile cotton swab was dipped into the inoculum and rotated against the wall of the tube above the liquid to remove excess inoculum. Entire surface of Muller Hinton agar was swabbed three times, rotating plates approximately $60^{\circ}$ between streaking to ensure even distribution. The inoculated plate was allowed to stand for at least $3 \mathrm{~min}$ but no longer than $15 \mathrm{~min}$ before punching the wells in the agar plate. A hollow tube of $5 \mathrm{~mm}$ diameter was taken and heated. It was pressed on the inoculated agar plate and removed immediately after making a well in the plate. Likewise, four wells were made on each plate. $50 \mu \mathrm{l}$ of AGE were added into the respective wells on each plate, and one of the well filled with sterile water and served as negative control. The plates were incubated within 15 min of compound application for $18-24 \mathrm{~h}$ at $37^{\circ} \mathrm{C}$. The antibacterial activity of AGE was determined based on clear inhibition zone around the wells. The results are shown as mean values from triplicate measurements.

\section{Determination of Minimum Inhibition Concentration by Microdilution Assay}

The Minimum inhibitory concentrations (MICs) were determined using standard Microdilution test of according to the recommendation CLSI [26]. The MDR bacteria isolates were grown overnight to log-phase in Luria-Bertani (LB) broth with shaking (170 rpm) at $37^{\circ} \mathrm{C}$ and suspended in sterile phosphate buffer saline (PBS) to a concentration of cells equal to $0.5 \mathrm{McFarland}$ with the absorbance range of 0.09 . After that, they were diluted in Mueller Hinton broth and to obtain a final inoculum concentration of $2 \times 10^{5} \mathrm{CFU} / \mathrm{mL}$. Subsequently, $100 \mu \mathrm{L}$ of bacterial suspension and $100 \mu \mathrm{L}$ of two fold serial AGE dilution (at concentrations ranged from 5 to $640 \mathrm{mg} / \mathrm{mL}$ ) in MHB or $100 \mu \mathrm{L}$ MHB without AGE were added into 96-well polystyrene microtiter plates and the absorbance of each well was read at $600 \mathrm{~nm}$. The plate was incubated at $37^{\circ} \mathrm{C}$ for $24 \mathrm{~h}$ and the absorbance was read again at the same wavelength. All experiments were performed in triplicate. The MIC of AGE was defined as the lowest concentration that completely inhibited the bacterial growth.

\section{Determination of Minimum Bactericidal Concentration}

For determining The minimum bactericidal concentration (MBC) values, an aliquot $(10 \mu \mathrm{L})$ of MIC mixtures that showed no growth was inoculated onto Mueller Hinton plates and incubated at 
$37^{\circ} \mathrm{C}$ for $24 \mathrm{~h}[26] . \mathrm{MBC}$ values were read as the lowest concentration of AGE required for a $99.9 \%$ reduction in the viable strains.

\section{Time-Kill Assay}

The time-kill effect of AGE were performed in microplate. The each column of microplate were prepared with $100 \mu \mathrm{L}$ of inoculum bacteria. The line one of microplate was set as a control. After which $100 \mu \mathrm{L}$ of the AGE $1 \mathrm{mg} . \mathrm{ml}^{-1}$ (AGE1, AGE2 and AGE3) were added in the line two to four. Microplate tube were incubated at $37^{\circ} \mathrm{C}$ and optical density (OD) at $620 \mathrm{~nm}$ was observed at interval of every three hours up to 24 hours. The results obtained are the average of the three (AGE1, AGE2 and AGE3).

\section{Statistical Analysis}

The results were reported as mean \pm standard deviation $( \pm \mathrm{SD})$. comparisons of means were performed after each analysis of variance (ANOVA) to distinguish the antibacterial effect of AGE against negative and positive Gram bacteria.

\section{Results}

\section{Antibiotic Sensitivity}

The table 1 and figure 1 shows the antibiotics profile of several UTI'bacterial strains isolated from urine of women in Lomé. It show that the nine bacteria tested exhibit-varying degrees of resistance of standard antibiotics used in this study. The most sensitive antibiotics against the nine bacteria are Amikacin (83.33\%), Gentamycin (77.78\%), Imipenem (77.78\%) and Nalidixic acid $(55.56 \%)$. However, some antibiotics are poor sensitive against the bacteria tested. The most resistant antibiotic are Amoxicillin/ clavulanic acid (100\%) and Erythromycin (100\%), Cefotaxime $(83.33 \%)$ and Ceftazidime $(83.33 \%)$. It's reveal that uropathogene bacteria strains in this study present high levels of multidrug resistances.

\section{Antibacterial effect of garlic extract against all bacteria isolates}

The results of inhibitory diameters, MICs and MBCs of garlic are show in figure 2 and Table 2. Garlic have reveal an antibacterial activity against all tested bacteria (Figure 2); the diameters of inhibition ranged from $20 \pm 3 \mathrm{~mm}$ (Klebsiella oxytoca) to $45 \pm 1 \mathrm{~mm}$ (E. faecalis) against the nine multidrug resistance bacteria tested. Garlic extracts displayed varying degrees of activity against uropathogene bacteria. It can be see that garlic extract MIC and $\mathrm{MBC}$ ranging from five $\%(\mathrm{w} / \mathrm{v})$ for Gram-Positive bacteria to $12.5 \%(\mathrm{w} / \mathrm{v})$ for Gram-Negative bacteria. This MICs and MBCs inhibit the growth of all tested bacteria.

\section{Time kill Curve}

Figure 3, represent the time kill effect against the nine MDR bacteria strains tested. It were performed by spectroscopic method. According to the results (Figure 3), the untreated (control) bacterial suspension shows time dependent increased absorbance at $600 \mathrm{~nm}$ indicates growth of bacteria; comparatively the treat (AGE) bacterial suspension shows less absorbance. Thus shows different bactericidal action of AGE. Staphylococcus saprophyticus, Staphylococcus aureus and Enterococcus faecalis are destroy after nine hours of incubation, but Escherichia coli, Klebsiella oxytoca, Klebsiella pneumoniae, Citrobacter freundii, Proteus mirabilis and Enterobacter aerogenes are destroy after 24 hours. That is reveal, AGE are more killing potential of GPB than GNB.

\subsection{Figures, Tables and Scheme}



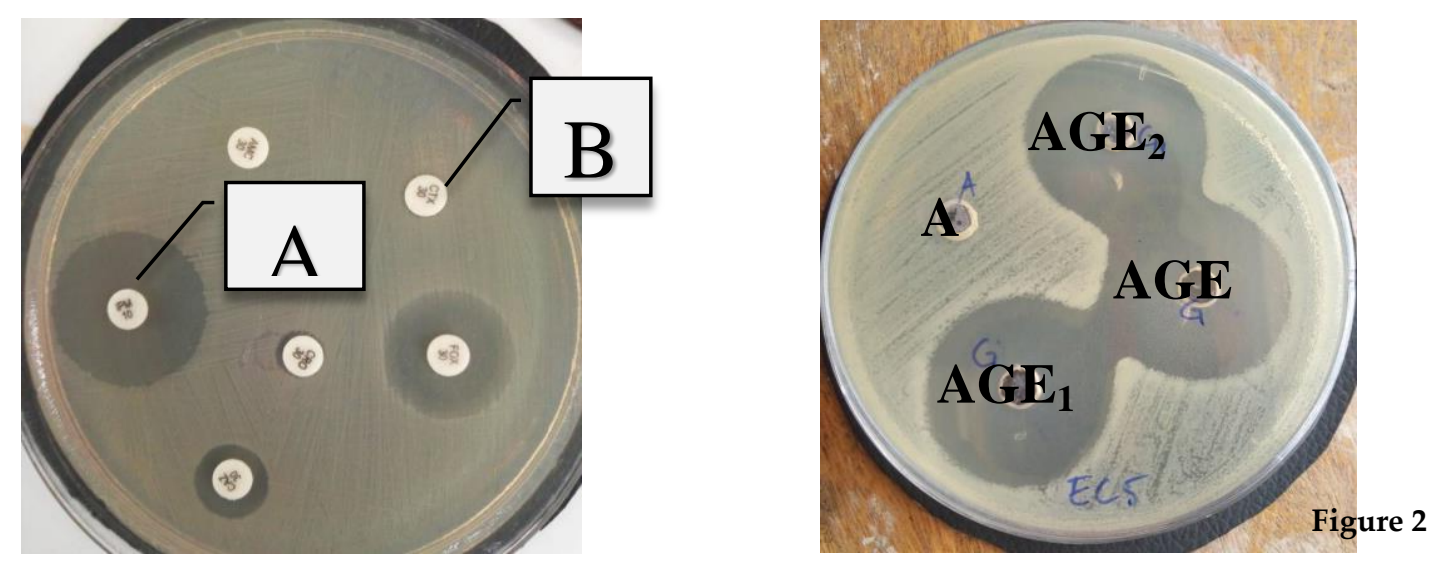

Figure 1. Antibiotics susceptibility against Proteus mirabilis isolated in women UTIs. A: presence of zone inhibition around the antibiotic (Imipenem) disc witch show the effect of this antibiotic against Proteus mirabilis. B: there are nothing around the antibiotic (Cefotaxime) disc then it show that Proteus mirabilis are $100 \%$ resistant to this antibiotic.

Figure 1. Antibacterial activity of garlic against Escherichia coli. AGE, AGE1 and AGE2: 50 $\mu$ of AGE at $50 \%(\mathrm{w} / \mathrm{v})$; A: $50 \mu \mathrm{l}$ of sterile water (DNAse and RNAse Free)
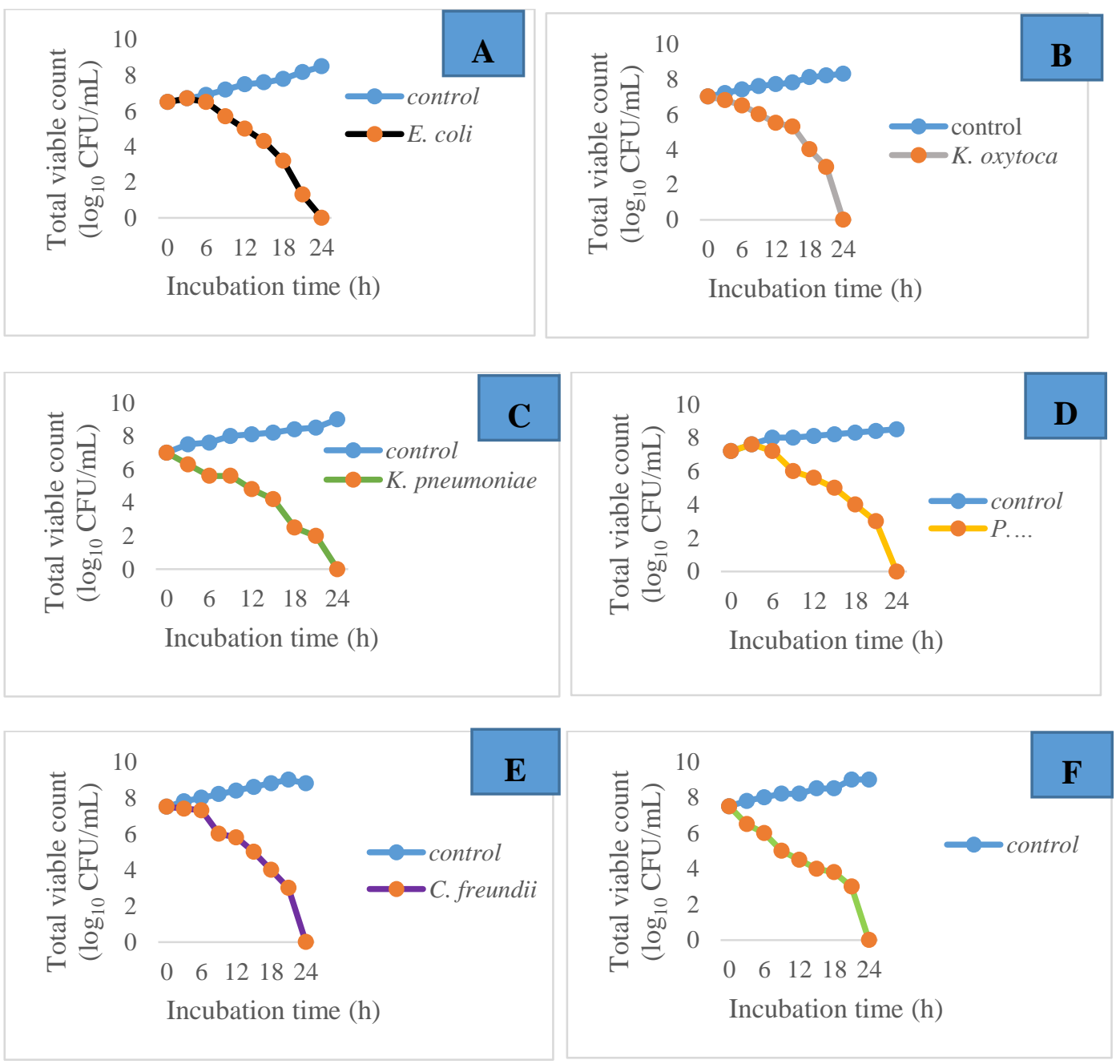

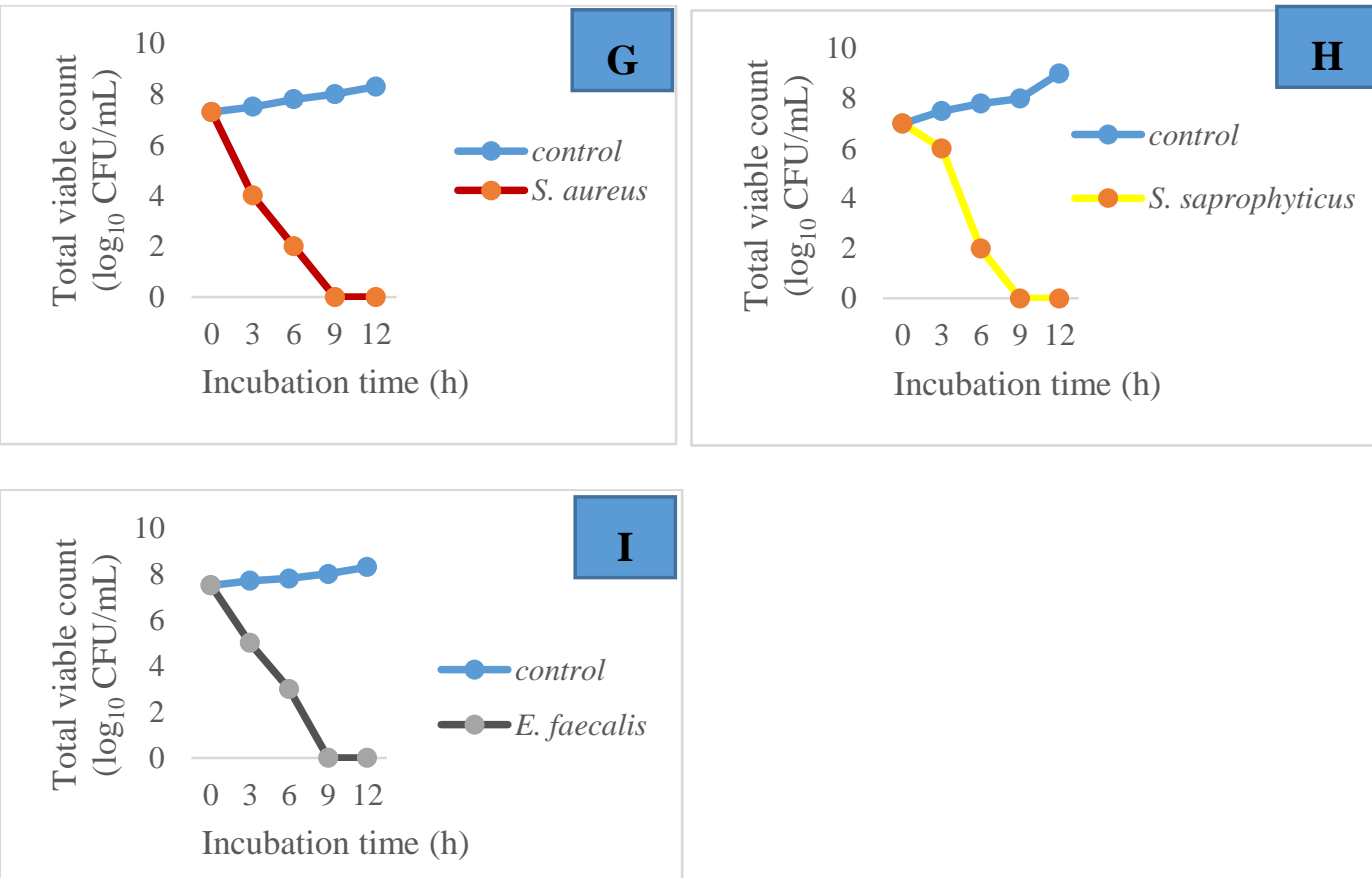

Figure 2. Time bactericidal effect of Togolese garlic on Gram-positive and negative bacteria. A: Escherichia coli; B: Klebsiella oxytoca; C: Klebsiella pneumoniae; D: Proteus mirabilis; E: Citrobacter freundii; F: Enterobacter aerogenes; G: Staphylococcus aureus; H: Staphylococcus saprophyticus; I: Enterococcus faecalis.

Table 1. Antibiotics susceptibility of bacteria strains isolated in women urinary tract infection

\begin{tabular}{|c|c|c|c|c|c|c|c|c|c|c|c|c|c|c|c|}
\hline & $\begin{array}{l}\text { AMC } \\
20 / 10\end{array}$ & $\begin{array}{l}\text { CTX } \\
5\end{array}$ & $\begin{array}{l}\text { CAZ } \\
30\end{array}$ & $\begin{array}{l}\text { FOX } \\
30\end{array}$ & $\begin{array}{l}\mathrm{AK} \\
30\end{array}$ & $\begin{array}{l}\mathrm{CN} \\
500\end{array}$ & $\begin{array}{l}\text { IMP } \\
10\end{array}$ & CIP 5 & $\begin{array}{l}\text { NA } \\
30\end{array}$ & $\begin{array}{l}\text { VA } \\
30\end{array}$ & K30 & PT 15 & L15 & E15 & C30 \\
\hline E. coli & $\mathrm{R}$ & $\mathrm{R}$ & S & S & s & S & S & s & $\mathrm{s}$ & ND & s & $\mathrm{ND}$ & ND & $\mathrm{ND}$ & $\mathrm{R}$ \\
\hline K. oxytoca & $\mathrm{R}$ & S & $\mathrm{R}$ & $\mathrm{R}$ & S & S & S & S & $\mathrm{R}$ & ND & $\mathrm{R}$ & $\mathrm{ND}$ & ND & $\mathrm{ND}$ & $\mathrm{R}$ \\
\hline K. pneumoniae & $\mathrm{R}$ & $\mathrm{R}$ & $\mathrm{R}$ & $\mathrm{R}$ & S & S & S & $\mathrm{R}$ & S & ND & $\mathrm{R}$ & $\mathrm{ND}$ & ND & $\mathrm{ND}$ & $\mathrm{R}$ \\
\hline K. ozonae & $\mathrm{R}$ & $\mathrm{R}$ & $\mathrm{R}$ & $\mathrm{R}$ & $\mathrm{R}$ & S & S & $\mathrm{R}$ & S & ND & $\mathrm{R}$ & $\mathrm{ND}$ & ND & $\mathrm{ND}$ & S \\
\hline C. freudii & $\mathrm{R}$ & $\mathrm{R}$ & $\mathrm{R}$ & S & $\mathrm{s}$ & S & S & $\mathrm{R}$ & $\mathrm{S}$ & ND & S & $\mathrm{ND}$ & ND & $\mathrm{ND}$ & $\mathrm{R}$ \\
\hline E. aerogenes & $\mathrm{R}$ & $\mathrm{R}$ & $\mathrm{R}$ & S & S & s & S & $\mathrm{s}$ & S & ND & $\mathrm{R}$ & ND & ND & $\mathrm{ND}$ & S \\
\hline S. aureus & ND & ND & ND & $\mathrm{R}$ & ND & S & S & $\mathrm{R}$ & $\mathrm{R}$ & $\mathrm{R}$ & $\mathrm{R}$ & $\mathrm{R}$ & $\mathrm{R}$ & $\mathrm{R}$ & $\mathrm{R}$ \\
\hline S. saprophyticus & ND & ND & ND & $\mathrm{R}$ & ND & $\mathrm{R}$ & $\mathrm{R}$ & $\mathrm{s}$ & $\mathrm{R}$ & $\mathrm{R}$ & $\mathrm{R}$ & S & S & $\mathrm{R}$ & $\mathrm{R}$ \\
\hline E. faecalis & ND & ND & ND & $\mathrm{R}$ & ND & $\mathrm{R}$ & $\mathrm{R}$ & $\mathrm{R}$ & $\mathrm{R}$ & S & $\mathrm{s}$ & $\mathrm{R}$ & $\mathrm{R}$ & $\mathrm{R}$ & $\mathrm{S}$ \\
\hline $\begin{array}{l}\text { Susceptible } \\
\text { percentage (\%) }\end{array}$ & 0 & 16,67 & 16,67 & 33,33 & 83,33 & 77,78 & 77,78 & 44,44 & 55,56 & 33,33 & 33,33 & 33,33 & 33,33 & 0 & 33,33 \\
\hline
\end{tabular}

AMC : Amoxicillin/ clavulanic acid, CTX : Cefotaxime, CAZ : Ceftazidime, FOX : Cefoxitin, AK : Amikacin, CN : Gentamycin, IMP : Imipenem, CIP : Ciprofloxacin, NA : Nalidixic acid, VA : Vancomycin, K : Kanamycin, PT : Pefloxacine, L : Lymcomycin, E : Erythromycin, C : Chloramphenicol, $R$ : Resistance, $S:$ Susceptibility, ND : Not Determined,

Table 2. Effect of aqueous garlic extract against strains isolated in women urinary tract infection 


\begin{tabular}{|c|c|c|c|}
\hline \multirow[t]{2}{*}{ Strains } & \multicolumn{3}{|c|}{ Aqueous garlic extract } \\
\hline & $\mathrm{DZI}(\mathrm{mm} \pm \mathrm{SD})$ & MIC & MBC \\
\hline E. coli & $32 \pm 4$ & 12,5 & 12,5 \\
\hline K. oxytoca & $20 \pm 3$ & 10 & 12,5 \\
\hline K. pneumoniae & $25 \pm 4$ & 10 & 12,5 \\
\hline P. mirabilis & $27 \pm 3$ & 10 & 12,5 \\
\hline C. freundii & $23 \pm 2$ & 10 & 12,5 \\
\hline E. aerogenes & $28 \pm 2$ & 10 & 12,5 \\
\hline S. aureus & $45 \pm 1$ & 5 & 5 \\
\hline S. saprophyticus & $38 \pm 2$ & 5 & 10 \\
\hline E. faecalis & $45 \pm 1$ & 5 & 10 \\
\hline
\end{tabular}

$\mathrm{DZI}(\mathrm{mm} \pm \mathrm{SD})$ : Diameter of Inhibition $(\mathrm{mm} \pm \mathrm{SD})$; MIC: Minimum Inhibition Concentration; MBC: Minimum Bactericidal Inhibition.

\section{Discussion}

In Table 1, the antibacterial susceptibility testing revealed that bacteria strains are multidrug resistance to standard antibiotics; similar results were previously reported[10, 12, 28]. However, some bacteria strains exhibited poor sensibility to $B$ lactamins family, aminosid (18.5\%) and fluoroquinolones groups (44.4\%). For women suffering from UTI, conventional management is based on low-dose antibiotic prophylaxis using trimethoprim-sulfamethoxazole $(40 \mathrm{mg} / 200 \mathrm{mg}$ daily), nitrofurantoin (100 mg/day), or cephalexin (250 mg daily)[11, 29]. The use of some antibiotics such as sulfonamide, trimethoprim, quinolones, tetracycline and aminoglycoside was known to increase the health risk[30,31][11]. Thus, there is an urgent requirement for the development of new drugs constituting an alternative to standard antibiotics, which are not risk for women during pregnancy.

From Table 2, the inhibition zone values showed that the garlic extract had high antibacterial activity against the nine MRB tested. The inhibition diameters range from $20 \pm 3$ to $32 \pm 4 \mathrm{~mm}$ and MICs range from 10 to $12.5 \%$ in Gram-negative bacteria. Gram-positive bacteria exhibited inhibition diameters range from $38 \pm 2$ to $45 \pm 1 \mathrm{~mm}$, and the MIC and MBC values are 5\% (weight / volume). These results are consistent with an earlier study but with less inhibitions diameters zone[22, 24]. The higher potency of Togolese garlic could be related to several factors, including climatic conditions, conferring different properties to garlic due to differences in chemical composition of lipids, proteins, vitamins and carbohydrates that seem to influence antimicrobial activity [13]. 
In addition, Figure 1 show the effect of garlic on the viability of bacterial strains in time. It's demonstrate that the treatment of bacterial strains with garlic extract was able to kill in nine hours (Gram-positive bacteria) to twenty-four hours (Gram- negative bacteria). The bactericidal action of garlic extract appears to be different depending on the bacterial strain. This was probably related to the composition of the cell envelope[32, 33]. Garlic extract interacts with the cell wall and changes the lipid membrane profile, demonstrating the shorter Gram-positive destruction time than the negative

\section{Conclusions}

In conclusion, the aqueous garlic extract have great potential as antibacterial agent against the nine multidrug resistance bacteria strains examined. Therefore, Togolese garlic may be a promising alternative that could replace antibiotics used in the treatment of urinary tract infections, especially in pregnant women whose use conventional antibiotics that will have repercussions on the health of mother and child. There is a continuous need for the development of new strategies for treatment of UTIs and further investigations are necessary to appreciate in vivo effect of garlic for develop garlic medical use, and promote them.

Author Contributions: Y.A.A. and B.G. conceived and designed the experiments; S.D.K., J.S., and Y.A.A performed the experiments; Y.A.A., J.S., and A.K.O. contributed to the reagents/analysis tools; E.T., A.K.O. and B.G. analyzed the data and drafted the manuscript; B.G. wrote the paper. Y.A.A. supervised the research.

Funding: This research received no external funding.

Conflicts of Interest: The authors declare no conflict of interest

\section{References}

1. Lo DS, Shieh HH, Barreira ER, Ragazzi SLB, Gilio AE. High frequency of Staphylococcus saprophyticus urinary tract infections among female adolescents. The Pediatric infectious disease journal 2015, 34:1023-1025

2. Flores-Mireles AL, Walker JN, Caparon M, Hultgren SJ. Urinary tract infections: epidemiology, mechanisms of infection and treatment options. Nature reviews microbiology 2015, 13:269

3. Heytens S, De Sutter A, Coorevits L, Cools P, Boelens J, Van Simaey L, Christiaens T, Vaneechoutte M, Claeys G. Women with symptoms of a urinary tract infection but a negative urine culture: PCR-based quantification of Escherichia coli suggests infection in most cases. Clinical Microbiology and Infection 2017, 23:647-652

4. Mlaga K, Dubourg G, Abat C, Chaudet H, Lotte L, Diene S, Raoult D, Ruimy R, Rolain J-M. Using MALDI-TOF MS typing method to decipher outbreak: the case of Staphylococcus saprophyticus causing urinary tract infections (UTIs) in Marseille, France. European Journal of Clinical Microbiology \& Infectious Diseases 2017, 36:2371-2377

5. Salou M, Yehadji D, Ekouevi K, Dossim S, Tsogou C, Nyasenu YT, Lack F, Prince-David M, Dagnra AY. Ciprofloxacin Sensitivity of Staphylococcus Strains Isolated at the Sylvanus Olympio University Hospital, Togo. Pharmacology \& Pharmacy 2014, 5:1143

6. Rasamiravaka T, Sheila HS, Rakotomavojaona T, Rakoto-Alson A, Rasamindrakotroka A. Changing profile and increasing antimicrobial resistance of uropathogenic bacteria in Madagascar. Medecine et maladies infectieuses 2015, 45:173-176 
7. Taale E, Sanou S, Sangare I, Abdelkerim A, Mbatna A, Sirima C, Savadogo A. Urinary tract infection among pregnant women at Bobo-Dioulasso: epidemiological and bacteriological aspects. Journal of Fundamental and Applied Sciences 2016, 8:1132-1145

8. Momoh A, Orhue P, Idonije O, Oaikhena A, Nwoke E, Momoh A. The antibiogram types of Escherichia coli isolated from suspected urinary tract infection samples. Journal of Microbiology and Biotechnology Research 2017, 1:57-65

9. Tängdén T, Giske C. Global dissemination of extensively drug-resistant carbapenemase-producing E nterobacteriaceae: clinical perspectives on detection, treatment and infection control. Journal of Internal Medicine 2015, 277:501-512

10. Dossim S, Salou M, Ekouevi D, Azimti A, Segbena A, Prince-David M, Dagnra A. Sensibilite des souches d'Escherichia coli isolees sur deux annees (2009-2010) aux $\beta$-lactamines et quinolones au laboratoire de microbiologie du CHU Campus de Lome. Journal de la Recherche Scientifique de l'Universite de Lome 2017, 19:227-235

11. Foudaa A, Seglab T, Mounerouc S, Adawayeh C, Bertind T, Abdelsalame T, Kodjof D, Yaovig A. Sensibility of uropathogens in pregnant women with asymptomatic bacteriuria in Lome, Togo. Scientific Journal of Biological Sciences 2015, 4:30-35

12. Tengue K. Prise en charge des urgences urologiques au Togo. Revue Africaine d'Urologie et d'Andrologie 2017, 1,

13. Gupta D, Dubey J, Kumar M. Phytochemical analysis and antimicrobial activity of some medicinal plants against selected common human pathogenic microorganisms. Asian Pacific Journal of Tropical Disease 2016, 6:15-20

14. Marasini BP, Baral P, Aryal P, Ghimire KR, Neupane S, Dahal N, Singh A, Ghimire L, Shrestha K. Evaluation of antibacterial activity of some traditionally used medicinal plants against human pathogenic bacteria. BioMed research international 2015, 2015,

15. Karou SD, Tchacondo T, Tchibozo MAD, Anani K, Ouattara L, Simpore J, De Souza C. Screening Togolese medicinal plants for few pharmacological properties. Pharmacognosy research 2012, 4:116

16. Tchacondo T, Karou SD, Agban A, Bako M, Batawila K, Bawa ML, Gbeassor M, de Souza C. Medicinal plants use in central Togo (Africa) with an emphasis on the timing. Pharmacognosy research 2012, 4:92

17. GAMBOGOU B, ANANI K, Simplice DK, Yaovi AA, SIMPORE J. Effect of Aqueous garlic extract on biofilm formation and antibiotic susceptibility of multidrug-resistant uropathogenic Escherichia coli clinical isolates in Togo. Int J Adv Multidiscip Res 2018, 5:23-33

18. Alfa T, Anani K, Adjrah Y, Batawila K, Ameyapoh Y. Ethnobotanical Survey of Medicinal Plants Used Against Fungal Infections in Prefecture of Sotouboua Central Region, Togo. European Scientific Journal, ESJ 2018, 14,

19. Agbodeka K, Gbekley HE, Karou SD, Anani K, Agbonon A, Tchacondo T, Batawila K, Simpore J, Gbeassor M. Ethnobotanical Study of Medicinal Plants Used for the 
Treatment of Malaria in the Plateau Region, Togo. Pharmacognosy Res 2016, 8:S12-18,10.4103/0974-8490.178646.

20. Oosthuizen CB, Reid A-M, Lall N: Garlic (Allium sativum) and Its Associated Molecules, as Medicine. In Medicinal Plants for Holistic Health and Well-Being. Elsevier; 2018: 277-295

21. Khan S. Antioxidant properties of garlic essential oil and its use as a natural preservative in processed food. Int J Commun Syst 2017, 5:813-821

22. Johnson M, Olaleye ON, Kolawole OS. Antimicrobial and Antioxidant Properties of Aqueous Garlic (Allium sativum) Extract against Staphylococcus aureus and Pseudomonas aeruginosa. British Microbiology Research Journal 2016, 14,

23. Böhme K; Barros-Velázquez J, Calo-Mata P, Aubourg SP. Antibacterial, antiviral and antifungal activity of essential oils: Mechanisms and applications. In Antimicrobial Compounds. Springer; 2014: 51-81

24. Fratianni F, Riccardi R, Spigno P, Ombra MN, Cozzolino A, Tremonte P, Coppola R, Nazzaro F. Biochemical characterization and antimicrobial and antifungal activity of two endemic varieties of garlic (Allium sativum L.) of the campania region, southern Italy. Journal of medicinal food 2016, 19:686-691

25. Petropoulos S, Fernandes Â, Barros L, Ciric A, Sokovic M, Ferreira IC. Antimicrobial and antioxidant properties of various Greek garlic genotypes. Food chemistry 2018, 245:7-12

26. Wayne P. Clinical and laboratory standards institute. Performance standards for antimicrobial susceptibility testing 2007, 17,

28. Diarra B, Ouattara AK, Wendkuuni Djigma F, Rebeca Compaore T, Obiri-Yeboah D, Traore L, Theophile Soubeiga S, Bado P, Yara J, Pietra V, et al. World Hepatitis Day in Burkina Faso, 2016: Awareness, Screening, Identification of HBV Markers, HBV/HCV Coinfection, and Vaccination. Hepat Mon 2017, 17:e13789,10.5812/hepatmon.13789.

30. Douti K, Djadou K, Leloup R, Tchakp I, Bakonde B, Agbere D, Kessie K. Infection urinaire chez l'enfant au CHU-Campus. Prévalence et sensibilité des germes. Journal de la Recherche Scientifique de l'Université de Lomé 2013, 15:333-337

31. Lukuke HM, Kasamba E, Mahuridi A, Ngatu NR, Narufumi S, Mukengeshayi AN, Malou V, Makoutode M, Kaj FM. L'incidence des infections nosocomiales urinaires et des sites opératoires dans la maternité de l'Hôpital Général de Référence de Katuba à Lubumbashi en République Démocratique du Congo. Pan African Medical Journal 2017, 28,

32. Banla IL, Kommineni S, Hayward M, Rodrigues M, Palmer KL, Salzman NH, Kristich CJ. Modulators of Enterococcus faecalis cell envelope integrity and antimicrobial resistance influence stable colonization of the mammalian gastrointestinal tract. Infection and immunity 2017:IAI. 00381-00317 
33. Segura A; Bernal P, Pini C, Krell T, Daniels C, Ramos J-L. Membrane composition and modifications in response to aromatic hydrocarbons in gram negative bacteria. In Handbook of Hydrocarbon and Lipid Microbiology. Springer; 2010: 1595-1603 